\title{
Hoani and Hiwa
}

"Hoani time to get up." Dang it Mum it's the weekend.

"What did you say boy?"

Oh, shit. Did I say that out loud? "Sorry Mum!"

Far out. Why are we getting up so early for, it's legit only 6am.

"Ok you three have 10 minutes to pack your bags and get in the car.

Kia tere!" The only time we get up this early is when we go home to the Hokianga to see Koro. DANG IT. Why are we going to Koro's house man, it's so boring up there.

I haven't been back home to Hokianga since I was 10, I'm 14 now.

Turns out we're going to Koro's to celebrate Matariki, the Māori New Year.

Sounds boring aye. Yeah, thought so hahahaha.

It's only me, my mum Tania, my little bro and sis Manaia and Kura.

My dad died 6 months ago from cancer, I don't remember the name of what he had other than it started with an L and had something to do with his blood. Cancer sucks man. I miss him so much, all the memories we had together were funny as 
memories, like the times he would take me to my rugby games and act if he was the coach yelling at the refs. Those times we would go to the beaches and go diving for kaimoana. Just everything about him I miss. Ever since dad died, Mum hasn't been the same. She doesn't smile as much, even though she tries her hardest to hide it and stay happy for us kids, but I can tell it has been hard for her. Sometimes I forget that I can be an idiot towards Mum but I don't mean too, it just happens. The only reason why I don't want to go back up north is because it brings back happy memories of us with Dad.

It just wouldn't feel the same yah know. But I'm going to try my hardest to behave for Mum. I can do this for her, I've got this.

"We're here kids" Mum said. Wait, what already? That was fast oh my god.

Aw wait. Well it is 10 o'clock, it makes sense. Geez it's boring here already and we've only just arrived, I wanna go home. "Mum can we go home please." "We are home Hoani" mum said. "I mean as in home, home like back in Auck, wait never mind don't listen to me." "Kids run inside and surprise Koro" she said as she walked inside. As they ran inside, I ran the other way towards the car. "Hoani stop being a dick", "I'm not being a dick Mum" I said. "Well, you sure are acting like one, get your butt inside." Remember Hoani we're behaving for Mum, "Ok fine, sorry Mum."

"Sup Koro, how have you been?" Hahaha, Koro still looks the same, like a hairless cat. Nah. Jokes, bahahaha! "Well, tiro mai ki au kua tawhito haere e moko." 
I already knew that, hahaha but didn't wanna be mean. "Nah, you don't look a day over 21 Koro, you still look skux." His whare still smells the same, like old people, but more like Nan. She died when I was 10. It's been four years and the house still smells the same and looks the same. "Kids help me unpack the car please and take our things to the shed please." Well, yup I haven't missed this place a bit. We're still sleeping in the old iron tin shed. It looks like a shed but it's more like an old sleepout that used to be a shed. So, it's still a shed to me. HONK, HONK!! What the heck was that? Oh cool, it's Aunty, Uncle and the cousins. "Hey neph, come give your favourite Aunty a hug!" She still smells the same, like cigarettes hahaha. "Hey Uncle, hey Tama, hey Tira" I said. "Kia ora Neph.", "Wassup g!", "Hey". If I'm being honest, I'm glad Tama is here, it's not gonna be as boring as I thought. THANK GOD. "Well you kids go play or do whatever you want and be back by $5 \mathrm{pm}$ in time for dinner and Koro has a surprise for you all after dinner." Aunty Mahuru said.

Kura, Tira and Manaia did whatever young ones do, while me and Tama went down to the beach for a swim, even though it was during the middle of winter, we're tough.

Both Tama and I heard Mum banging the pots and screaming, realising it was time to go back for dinner and the 'special surprise' Koro had for us. Dinner was pretty yum. We had boil up, kaimoana and roasted veges. "What's the surprise?", "Yeah, what's our surprise?"

"Well kids in celebration of Matariki, you are all going on a little adventure with Koro!"

Oh aye? What a dumb surprise hahaha, I thought 
we were gonna get a box of chocolates or something. Not going out on an adventure with Koro and its dark outside as well. "So, get some warm clothes, some gumboots and take a torch as well. Koro is taking you all to his favourite spot around this time of year. When you arrive that's your surprise and you all are lucky as the sky is crystal clear tonight. We went as kids on this adventure and it's 100 percent worth it kids. So be patient with Koro as he is a little older now. But it is worth it I promise you." Mum said.

Mum is not usually the one to make promises, and yet her surprises are usually on the boring side, so I have high hopes for this one.

"Ka pai, let's go mokos" Koro said. "It's so cold!" Manaia said. "Well obviously it is Manaia, we're in the middle of winter." I replied but man he was right it was freezing, but bro if you could see how see how clear the sky is. Like honest to god, gee my jaw dropped, like it's pretty mean but 100 times better than mean. Gee, like even better than skux, it's even better than those flash English words that I can't pronounce. But Mum was right, it is worth it.

"Ka pai, mokopuna mā, kei kōnei mātou" Um, where's the surprise? We're just standing on a big grass hill in the middle of nowhere bahahaha. "Uh Koro, kua ngaro mātou?"

"E kao Hoani, kei kōnei mātou. Tiro atu ki runga ki te rangi, tiro atu ki ngā whetu."

WOAHHHHHHHHH! No words could explain how mean the sky was. Like what I said before, it's better than any flash English words that exist. The sight of the sky was amazing. You can hear the waves of the ocean breaking, the chirps of the 
crickets and the sky was so close you could touch it, it is amazing.

Koro told us to grab our blankets, to lay them out and to lie on our backs to have our eyes facing the sky. Well obviously we listened because none of us were ready to leave hahaha. "As you all stare up to the sky can you see the nine brightest stars in the sky?" "Āe koro!" everyone else said expect me because I couldn't see them, geez I must be blind. "Where bouts Koro?", “Tōtika atu Hoani, straight ahead" he said as he pointed at them for me. "Oh yo! Thank you Koro." I thought I was going blind for a sec, but I was looking elsewhere. "Ko aua whetu rā, ko tērā te whānau o Matariki, ngā tuahine e iwa o Matariki. They are nine sisters that make up the family of Matariki and each of them have their own special meaning and powers. Matariki, Tupuānuku, Tupuārangi, Waipuna-āRangi, Wait̄i, Waita, Ururangi, Pōhutukawa and lastly Hiwa-i-te-Rangi.

Matariki is the star that signifies reflection, hope, our connection to the environment, and the gathering of people. Tupuanuku is the star that is connected to kai and rongoā that grow from the soils of Papatūānuku. Tupuarangi is the star connected to kai and rongoā growing from above in the sky, such as birds and food from the trees. Waipuna-ā-Rangi is connected to the rain, the tears of Ranginui. Waitī and Waitā are mahanga, twins. Waitī is connected to the kai in freshwater such as the lakes, streams and rivers. While Waitā is connected to the many kinds of kai in salted water, from the moana. Ururangi is connected to the winds of Tawhirimatea and Pōhutukawa is the 
star connected to those who have passed. That was only eight stars I thought there were nine. "Um Koro, that was only eight what about the last one." Manaia said. "Aue, yes arohamai, last but not least Hiwa-i-te Rangi.

Hiwa-i-te-rangi is the star that grants your wishes. Each year people send their dreams and desires to Hiwa in hope they will come true. That is why we are here kids, each of you will get to make your wish of the year but choose carefully as you can only get one wish. However, you cannot wish for more wishes." Koro says.

DANG IT! I was going to wish for unlimited wishes. Ok one wish, want do I want.

A PlayStation 5? Nah I'm pretty Manaia will wish for one so I can just use his.

What about a new iPad or iPhone? Or Money? Or a new bike? Or for Kura to be less annoying? Nah hahahaha just kidding! Aw wait I've got it! "E Hiwa-i-te-rangi ānei tāku tino moemoeā, I wish for....."

Aye nothing happened, why did my wish not come true? "Koro why did my wish not come true?" I said, beginning to cry. I never usually cry but I was really hoping my wish would come true. "You know what, never mind." I started sprinting home with tears falling from my face, running into the room in the shed and slamming the door.

"Hoani what's wrong, what happened?" Mum asked standing outside of the bedroom door. "Koro told us to make a wish to Hiwa and mine didn't come true mum. I'm annoyed and angry so can you please leave me alone mum."

"Hoani, not all wishes and dreams come true in Godspeed, they take time so be patient okay son." 
No matter how much mum was trying to comfort me, I just wanted to be alone. But not matter how much I wanted to be alone, this was my first time having alone time with Mum like this since Dad died. I miss him so much man. Words cannot explain it. Once I said goodnight to Mum, I ended up crying myself to sleep.

"Hoani time to get up!" Dang it mum it's the weekend. "What did you say boy?" Shit did I say that out load again? "Sorry mum!" Hold up when did we get back home? "Mum when did we get back home, we were just at Koro's last night?" I'm so confused.

"Uh Hoani we're going there today, so pack your bags you have 10 minutes."

Oh, shoot it must've been all a dream. Ok whatever, at least I know now to make another wish. "Ok Mum I have my bags packed when are we leav..." I said as I walked towards the car until I seen "DADDDDDDD!" I've never been so happy in my life, I hugged him so tightly, he was probably confused about what the heck was going on. But bro my wish came true, OH MY GOD! "Thank you Hiwa." 